\title{
PENGARUH BIMBINGAN KLASIKAL DENGAN TEKNIK JOHARI WINDOW UNTUK MENINGKATKAN KETERBUKAAN DIRI DALAM KOMUNIKASI ANTAR TEMAN SEBAYA PADA SISWA KELAS XII SMA NEGERI 2 REMBANG
}

\author{
Oleh: Harnanda Nisrina Rosida*, Siti Fitriana** dan Ismah*** \\ Email: harnandanisrinarosida@gmail.com
}

\begin{abstract}
ABSTRAK
Penelitian dilatar belakangi oleh kurangnya keterbukaan diri dalam komunikasi antar teman sebaya. Tujuan yang hendak dicapai dalam penelitian ini adalah untuk mengetahui pengaruh bimbingan klasikal dengan teknik Johari Window untuk meningkatkan keterbukaan diri dalam komunikasi antar teman sebaya pada siswa kelas XII SMA Negeri 2 Rembang. Jenis penelitian ini adalah penelitian kuantitatif dengan pendekatan quasi eksperimental design dengan desain pretestposttest (one group prettest-posttest). Hasil analisis dengan menggunakan Uji-t. Uji validitas instrument penelitian menggunakan rumus Product Moment dan dilanjutkan uji reliabilitas menggunakan rumus Alpha. Hasil uji validitas instrumen diperoleh butir instrumen yang valid 37 butir dan 3 butir tidak valid digugurkan dengan koefisien reliabilitas sebesar 0,940. Berdasarkan hasil analisis data penelitian setelah mendapatkan perlakuan bimbingan klasikal dengan teknik Johari Window, menunjukkan adanya perkembangan keterbukaan diri dalam komunikasi antar teman sebaya. Dari hasil pengujian hipotesis menggunakan rumus t-test diperoleh thitung > tabel (2.103 > $2,042)$ dengan taraf signifikansi 5\% $(0,05)$ yang berarti bahwa ada pengaruh bimbingan klasikal dengan teknik Johari Window untuk meningkatkan keterbukaan diri dalam komunikasi antar teman sebaya pada siswa kelas XII SMA Negeri 2 Rembang.
\end{abstract}

Kata kunci: Bimbingan Klasikal dengan Teknik Johari Window, Keterbukaan Diri dalam Komunikasi Antar Teman Sebaya

\begin{abstract}
Research is motivated by a lack of openness in communication between peers. The aim to be achieved in this study is to determine the effect of classical guidance with the Johari Window technique to increase self-disclosure in peer communication among XII graders of SMA Negeri 2

Rembang. This type of research is quantitative research with a quasi-experimental design approach with a pretest-posttest (one group prettest-posttest) design. The results of the analysis using the $t$ - test. The validity test of the research instrument used the Product Moment formula and continued the reliability test using the Alpha formula. The results of the instrument validity test obtained 37 valid items and 3 invalid items were aborted with a reliability coefficient of 0.940 . Based on the results of the analysis of research data after getting classical guidance treatment with the Johari Window technique, it shows that there is a development of self-disclosure in communication between peers. From the results of hypothesis testing using the formula t-test obtained tcount> ttable (2.103> 2.042) with a significance level of 5\% (0.05) which means that there is an influence of classical guidance with the Johari Window technique to increase self-disclosure in communication between peers in students class XII of SMA 2 Rembang.
\end{abstract}

Keywords:Classical Guidance with the Johari Window Technique, Self-Openness in Peer Communication

*Harnanda Ristina Rosida, **Siti Fitriana, ***Ismah 


\section{PENDAHULUAN}

Berkomunikasi menjadi suatu keharusan dalam kehidupan manusia. Manusia senantiasa membutuhkan dan selalu berusaha membuka serta menjalin komunikasi atau hubungan dengan sesamanya. Hal lain yang menyebabkan terjadinya proses komunikasi dikarenakan sejumlah kebutuhan dalam diri manusia dapat dipuaskan lewat komunikasi dengan sesamanya. Kenyataannya, tidak semua orang bisa melakukan hubungan komunikasi dengan baik hal ini dikarenakan karena adanya rasa ketidakpercayaan, sehingga menyebabkan ketakutan akan rahasia yang terbongkar, rasa percaya diri yang kurang, merasa malu, dan takut terhadap akibat yang timbul di kemudian hari. Hal tersebut menyebabkan siswa lebih nyaman untuk menyendiri dan memendam perasaan.

Pembukaan diri atau self disclosure adalah mengungkapkan reaksi atau tanggapan terhadap situasi yang sedang dihadapi serta memberikan informasi tentang masa lalu yang relevan atau yang berguna untuk memahami tanggapan tentang hal tersebut di masa kini. Johnson dalam Supratiknya menyatakan tanggapan terhadap orang lain atau terhadap kejadian tertentu lebih melibatkan perasaan.

Masalah mengenai keterbukaan diri dalam komunikasi antar teman sebaya dialami oleh siswa kelas XII SMA Negeri 2 Rembang. Hasil analisis Angket Kebutuhan Peserta Didik (AKPD) siswa kelas XI SMA Negeri 2

Rembang pada tanggal 17 September 2018 menunjukkan permasalahan-permasalahan dalam komunikasi yang dialami siswa. Setidaknya tercatat 16 siswa yang belum memahami etika dalam bergaul, 17 siswa merasa takut bertanya atau menjawab di dalam kelas, dan 26 siswa belum mengetahui cara berkomunikasi yang efektif. Hasil AKPD tersebut menunjukkan siswa masih mengalami kesulitan dalam menjalin komunikasi. Hal tersebut tidak terlepas dari kurangnya keterbukaan diri (self disclosure) yang dimiliki siswa, sehingga siswa tidak mampu mengatasi hambatan-hambatan dalam berkomunikasi.

Berdasarkan hasil wawancara yang dilakukan penulis terhadap guru BK SMA Negeri 2 Rembang pada tanggal 17 September 2018, diketahui bahwa siswa masih belum sepenuhnya dapat menunjukkan keterbukaan dalam komunikasi dengan teman sebaya. Perselisihan yang terjadi diantara teman sebaya belum dikemukakan untuk dicari solusi yang ada. Masing-masing siswa yang berselisih masih cenderung menutup diri dan menyimpan ketidaksenangan dengan teman. Kondisi tersebut mengakibatkan hubungan yang terjalin dengan temna terkesan jauh. Guru BK di SMA Negeri 2 Rembang belum memberikan layanan secara khusus untuk mengatasi masalah tersebut, namun cenderung menunggu permasalahan tersebut menjadi sebuah konflik nyata, seperti halnya dengan perkelahian. Penelitian ini bertujuan untuk mengetahui pengaruh bimbingan klasikal dengan teknik Johari Window untuk meningkatkan keterbukaan diri dalam komunikasi antar teman sebaya pada siswa kelas XII SMA Negeri 2 Rembang. Keterbukaan diri (dalam Eka Sari Setiangsih, 2015) merupakan faktor penting dalam konseling dan psikoterapi, terutama dalam proses pemberian bantuan terhadap orang lain. Individu akan lebih mampu menanggulangi 
masalah atau kesulitan, khususnya perasaan bersalah melalui keterbukaan diri. Salah satu perasaan takut yang besar pada diri banyak orang adalah bahwa individu tidak diterima lingkungan karena suatu rahasia tertentu. Keterbukaan diri memiliki manfaat bagi masing-masing individu maupun bagi hubungan antara kedua pihak. Dengan membuka diri dan membalas keterbukaan diri orang lain, siswa dapat meningkatkan komunikasi dan hubungan dengan orang lain, siswa yang rela membuka diri cenderung memiliki sifat-sifat kompeten, ekstrovert, fleksibel, adaptif dan intellegent. Seorang siswa yang terbuka akan lebih mudah untuk memecahkan permasalahan yang sedang dihadapi karena siswa mampu untuk bercerita dan meminta pendapat dari orang lain. Sebaliknya jika siswa dalam kehidupannya tidak terbuka, maka akan mengakibatkan sulit tercapainya komunikasi yang baik dan akan mengalami kesulitan sehingga siswapun akan mengambil keputusan negatif.

\section{Keterbukaan diri dalam}

\section{Komunikasi antar teman sebaya}

Keterbukaan diri dalam penelitian ini terkait dengan keterbukaan diri dalam komunikasi dengan teman sebaya. Manusia mempunyai naluri untuk berkelompok atau berkawan dengan manusia lain. Dalam kelompok tersebut manusia dituntut dapat berkomunikasi dengan orang lain agar tidak terisolasi dari pergaulan dilingkungannya. Istilah komunikasi (bahasa Inggris: communication) berasal dari communis (bahasa Latin) yang berarti sama (common), kemudian berubah menjadi kata kerja kommunicare,yaitu menyebarkan/ memberitahukan. Jadi menurut asal katanya, komunikasi berarti menyebarkan atau memberitahukan informasi kepada pihak lain guna mendapatkan pengertian yang sama (Zulkarnain, 2013: 62). Dalam berkomunikasi pada dasarnya individu tidak bisa langsung mengungkapkan apa yang akan diungkapkan. Untuk bisa mengungkapkan masalah atau informasi, hubungan antar individu haruslah akrab dan terbuka. Semakin orang mau terbuka untuk saling membicarakan sesuatu hal, maka semakin dalam taraf komunikasi yang terjadi. Hetherington dan Parke (dalam Desmita, 2005: 145) menyatakan bahwa teman sebaya (peer) sebagai sebuah kelompok sosial sering didefinisikan sebagai semua orang yang memiliki kesamaan sosial atau yang memiliki kesamaan ciri-ciri, seperti kesamaan tingkat usia. Chaplin (2011: 357) menyatakan teman sebaya adalah se (sama), baik secara sah maupun secara psikologis; kawan seusia. Dari uraian di atas maka dapat disimpulkan bahwa keterbukaan diri dalam komunikasi antar teman sebaya adalah kegiatan berbagi informasi tentang suatu pernyataan apa yang disangka, dikira tentang sesuatu (orang, peristiwa) yang tidak didasarkan fakta pembuktian, akan tetapi berdasar pada apa yang dilihatnya seperti benar atau mungkin kepada kawan seumuran secara terbuka dengan mempunyai tujuan dan keinginan yang sama.

\section{Bimbingan Klasikal dengan} TeknikJohari Window

Gibson (dalam Siwabessy dan Hastuti, 2008: 136) menyatakan bahwa bimbingan klasikal adalah suatu kelompok yang memiliki sesuatu aktivitas yang menyajikan informasi atau pengalamanpengalaman melalui suatu perencanaan dan pengorganisasian kelompok sebagai contoh bimbingan klasikal berorientasi pada penyampaian informasi dan 
eksplorasi karir dengan cara menyelenggarakan kunjungan- kunjungan siswa ke berbagai universitas atau instansi kampus untuk memberikan motivasi bagi siswa mengenai perguruan tinggi. Bimbingan klasikal sering disebut sebagai layanan dasar yaitu layanan bantuan bagi peserta didik (siswa) melalui kegiatankegiatan secara klasikal yang disajikan secara sistematis dalam rangka membantu siswa mengembangkan potensinya secara optimal (Yusuf dan Nurihsan, 2008: 26). Terdapat banyak cara untuk mengetahui diri dalam komunikasi, salah satunya adalah apa yang dikenal dengan istilah Johari Window. Johari Window dikenalkan pada tahun 1955 oleh dua orang ahli Psikologi Amerika, yakti Joseph Luft dan Harrington Ingham. Disebut sebagai Johari Window karena asal katanya "Jo" berasal dari nama John, sedangkan Hari berasal dari nama Harry. Melalui Johari Window seseorang bisa lebih mengerti bagaimana hubungan antara dirinya dengan orang lain (Nurudin, 2017: 185). Nurudin (2017: 186-196) menjelaskan bahwa Johari Window digambarkan dengan segiempat dengan jumlah bidang, yakni daerah open (terbuka), blind (buta), unknow (tidak diketahui), dan hidden (tersembunyi).

\section{METODE PENELITIAN}

Penelitian dengan judul pengaruh bimbingan klasikal dengan teknik Johari Window untuk meningkatkan keterbukaan diri dalam komunikasi antar teman sebaya pada siswa kelas XII SMA Negeri 2 Rembang. Dalam penelitian ini variabel bebas (independent) adalah bimbingan klasikal dengan teknik Johari Window (X) dan variabel terikat (dependent) adalah keterbukaan diri dalam komunikasi antar Teman Sebaya (Y).
Penelitian ini menggunakan metode penelitian eksperimen dalam rancangan penelitian dan menggunakan penelitian kuantitatif dalam pengolahan datanya. Jenis penelitian eksperimen ini adalah quasi eksperimental design. Alasan penggunaan jenis quasi eksperimental design karena dalam penelitian ini peneliti menggunakan kelompok kontrol yang akan diukur pada saat pre-test dan posttest design.

Desain penelitian yang digunakan oleh peneliti rancangan nonrandomized pretest-posttest control group design. Rancangan pra- eksperimental yang digunakan adalah jenis One group pretestposttest design, rancangan yang digunakan ini menggunakan kontrol yang minimal. Penelitian ini menggunakan desain pretestposttest (one group prettest- posttest). Dalam desain ekperimen pengukuran dilakukan dua kali. Pengukuran pertama dilakukan sebelum perlakuan diberikan, dan pengukuran kedua dilakukan sesudah perlakuan dilaksanakan. Pengaruh perlakuan diukur dari perbedaan antara pengukuran awal dan pengukuran akhir.

Dalam pengambilan sampel ini diambil dengan cara acak atau undian. Random dilakukan terhadap kelas XII IPA 1, XII IPA 2, XII IPA 3, XII IPA 4, XII IPA 5, XII IPS 1, XII IPS 2, XII IPS 3 dan XII Bahasa. Peneliti menetapkan dua kelas untuk kelompok kontrol dan eksperimen. Untuk kelompok kontrol menggunakan kelas XII IPS 3 dan kelompok eksperimen XII IPA 5. Dalam mengungkapkan data yang diinginkan maka digunakan metode pengumpulan data dengan menggunakan skala psikologis. Untuk mendapatkan hasil yang sesuai maka digunakan Uji T-test. 


\section{HASIL PENELITIAN DAN PEMBAHASAN}

Berdasarkan hasil pretest yang didapat baik dari kelompok kontrol maupun kelompok eksperimen, peneliti akan memaparkan hasilnya sebagai berikut:

Rentang kelas interval $=$

skor tertinggi - skor terendah

$$
\begin{aligned}
& 4 \\
& \text { Skor tertinggi }=148 \\
& \text { Skor terendah }=37 \\
& \text { Rentang = } \\
& \frac{148-37}{4}=\frac{111}{4}=27,75
\end{aligned}
$$

Tabel distribusi frekuensi bergolong sesuai dengan kategori jawaban skala psikologis keterbukaan diri dalam komunikasi antar teman sebaya pada siswa kelas XII SMA Negeri 2 Rembang sebagai berikut:

Tabel I

Kategori Interval

\begin{tabular}{|c|c|}
\hline Interval & Kategori \\
\hline $120,25-148$ & Sangat Tinggi \\
\hline $92,5-120,24$ & Tinggi \\
\hline $64,75-92,4$ & Rendah \\
\hline $37-64,74$ & Sangat Rendah \\
\hline & \\
\hline
\end{tabular}

Berdasarkan dari hasil pretest mengenai skala keterbukaan diri dalam komunikasi antar teman sebaya pada siswa kelas XII SMA Negeri 2 Rembang dapat diketahui dalam kelompok kontrol tidak ada siswa dikategori sangat rendah dengan interval kelas 37 - 64,74, satu siswa dikategori sangat tinggi dengan kelas interval 120,25 - 148 atau 3,12\%, empat siswa dikategori rendah dengan kelas interval 64,75 - 92,4 atau $12,5 \%$, serta dua puluh tujuh siswa dikategori tinggi dengan kelas interval 92,5 - 120,24 atau $84,38 \%$.

Dari hasil analisis data pretest kelompok kontrol mengenai keterbukaan diri dalam komunikasi antar teman sebaya pada siswa kelas XII SMA Negeri 2 Rembang dapat digambarkan dengan grafik sesuai kategori interval.

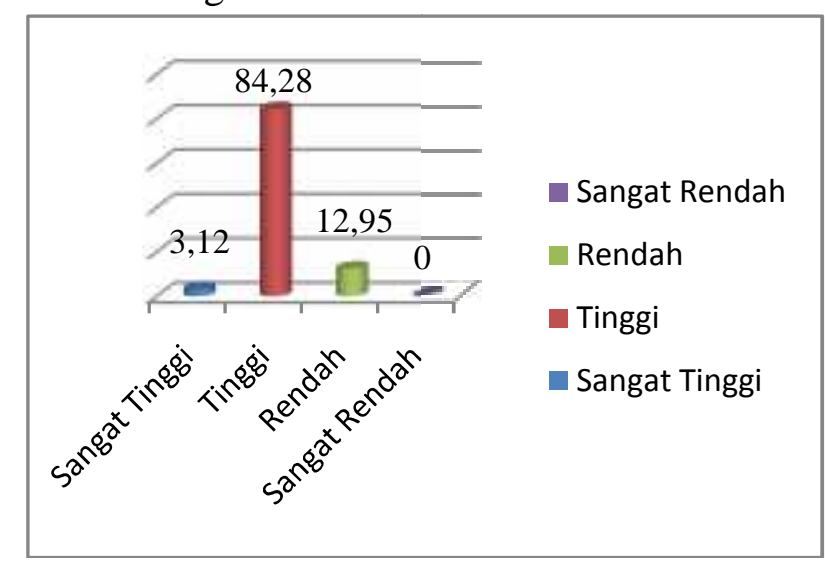

\section{Gambar 1}

\section{Grafik Pretest Keterbukaan Diri dalam Komunikasi Antar Teman Sebaya Kelompok Kontrol}

Berdasarkan dari hasil pretest mengenai skala keterbukaan diri dalam komunikasi antar teman sebaya pada siswa kelas XII SMA Negeri 2 Rembang dapat diketahui dalam kelompok eksperimen tidak ada siswa dikategori sangat rendah dengan interval kelas 37 - 64,74 dan sangat tinggi dengan kelas interval 120,25 - 148, dua puluh lima siswa dikategori tinggi dengan kelas interval 92,5 - 120,24 atau $78,12 \%$, serta tujuh siswa dikategori rendah dengan kelas interval 64,75 - 92,4 atau $21,88 \%$.

Dari hasil analisis data pretest kelompok eksperimen mengenai 
keterbukaan diri dalam komunikasi antar teman sebaya pada siswa kelas XII SMA Negeri 2 Rembang dapat digambarkan dengan grafik sesuai kategori interval.

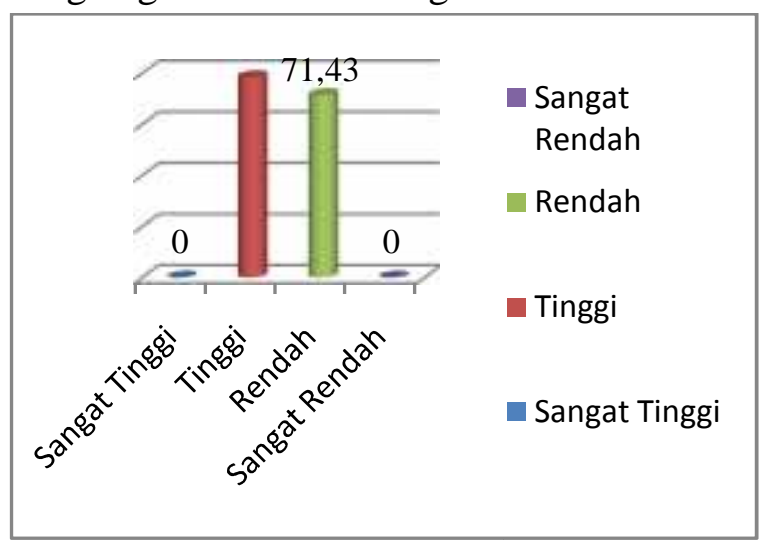

Gambar 2

Grafik Pretest Keterbukaan Diri dalam Komunikasi Antar Teman Sebaya Kelompok Eksperimen

Berdasarkan dari hasil posttest mengenai skala keterbukaan diri dalam komunikasi antar teman sebaya pada siswa kelas XII SMA Negeri 2 Rembang dapat diketahui dalam kelompok kontrol tidak ada siswa dikategori sangat rendah dengan interval kelas 37 - 64,74 dan sangat tinggi dengan kelas interval 120,25 - 148, empat siswa dikategori rendah dengan kelas interval $64,75-92,4$ atau $12,5 \%$, serta dua puluh delapan siswa dikategori tinggi dengan kelas interval 92,5 - 120,24 atau $87,5 \%$.

Dari hasil analisis data posttest kelompok kontrol mengenai keterbukaan diri dalam komunikasi antar teman sebaya pada siswa kelas XII SMA Negeri 2 Rembang dapat digambarkan dengan grafik sesuai kategori interval.

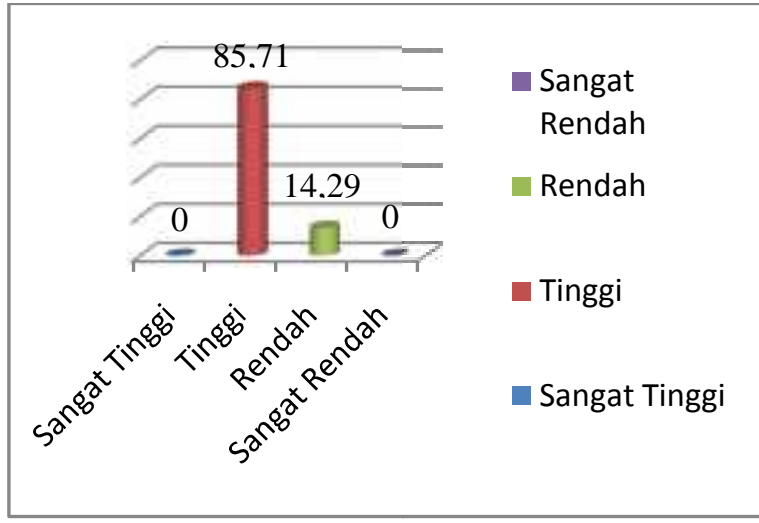

\section{Gambar 3}

Grafik Posttest Keterbukaan Diri dalam Komunikasi Antar Teman Sebaya Kelompok Kontrol

Berdasarkan dari hasil posttest mengenai skala keterbukaan diri dalam komunikasi antar teman sebaya pada siswa kelas XII SMA Negeri 2 Rembang dapat diketahui dalam kelompok eksperimen tidak ada siswa dikategori sangat rendah dengan interval kelas 37 - 64,74 dan sangat tinggi dengan kelas interval 120,25 - 148, dua puluh sembilan siswa dikategori tinggi dengan kelas interval 92,5 - 120,24 atau $90,63 \%$, serta tiga siswa dikategori rendah dengan kelas interval 64,75 - 92,4 atau 9,37\%.

Dari hasil analisis data posttest kelompok eksperimen mengenai keterbukaan diri dalam komunikasi antar teman sebaya pada siswa kelas XII SMA Negeri 2 Rembang dapat digambarkan dengan grafik sesuai kategori interval. 


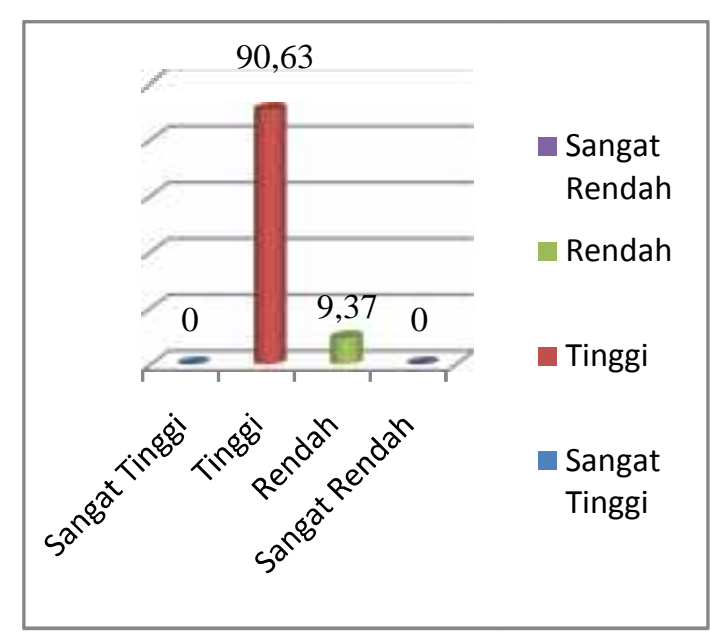

Gambar 4

Grafik Posttest Keterbukaan Diri dalam Komunikasi Antar Teman Sebaya Kelompok Eksperimen

Hasil analisis data menggunakan $U j i$ $T$ - test dengan bantuan program SPSS adalah sebagai berikut:

Tabel II

Hasil Uji T-test

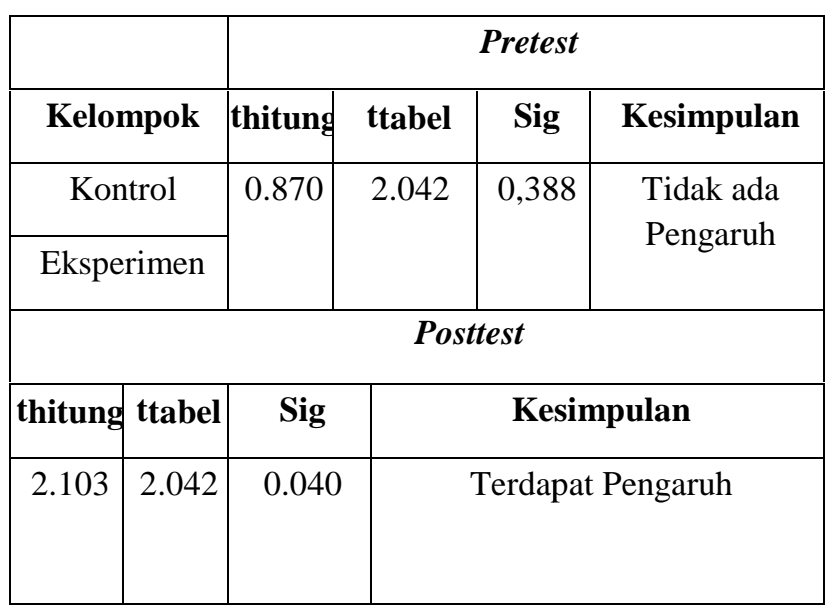

\section{PEMBAHASAN}

Berdasarkan hasil penghitungan analisis t test pada kelompok kontrol dan eksperimen saat pretest, diperoleh nilai thitung sebesar 0,032 sementara ttabel dengan taraf signifikan 5\% sebesar 2,042 dengan signifikansi 0,388 . Nilai thitung < ttabel $(0,032<2,042)$ yang berarti bahwa

tidak ada perbedaan keterbukaan diri dalam komunikasi antar teman sebaya pada siswa kelas XII SMA Negeri 2 Rembang pada kelompok kontrol dan kelompok eksperimen pada saat pretest.

Berdasarkan hasil penghitungan analisis $t$ test pada kelompok kontrol dan eksperimen saat posttest, diperoleh nilai thitung sebesar 2.103 sementara tabel dengan taraf signifikan 5\% sebesar 2,042 dengan signifikansi 0,040. Nilai thitung > tabel $(2.103>2,042)$ yang berarti bahwa ada perbedaan keterbukaan diri dalam komunikasi antar teman sebaya pada siswa kelas XII SMA Negeri 2 Rembang pada kelompok kontrol dan kelompok eksperimen pada saat posttest.

Jadi dapat disimpulkan bahwa bimbingan klasikal dengan teknik Johari Window dapat berpengaruh terhadap keterbukaan diri dalam komunikasi antar teman sebaya pada siswa kelas XII SMA Negeri 2 Rembang. Dengan demikian maka hipotesis kerja (Ha) berbunyi ada pengaruh bimbingan klasikal dengan teknik Johari Window untuk meningkatkan keterbukaan diri dalam komunikasi antar teman sebaya pada siswa kelas XII SMA Negeri 2 Rembang, diterima.

Hasil penelitian ini sejalan dengan temuan penelitian terdahulu yang dilakukan oleh Hanifa, dkk (2012) menunjukkan bahwa bimbingan kelompok melalui teknik Johari Window mampu meningkatkan keterbukaan diri dalam komunikasi antar teman sebaya pada siswa kelas XI IS 1 SMA Walisongo Pecangaan Jepara. Bimbingan klasikal dengan teknik Johari Window diharapkan dapat meningkatkan informasi yang dimiliki siswa mengenai pentingnya keterbukaan diri dalam komunikasi antar teman sebaya. Pemahaman yang diperoleh siswa melalui

*Harnanda Ristina Rosida, **Siti Fitriana, ***Ismah 51 
layanan informasi dengan teknik Johari Window dapat dipergunakan sebagai bahan acuan dalam komunikasi antar teman sebaya.

Berdasarkan hasil analisis data yang dilakukan dari hasil skor rata-rata pretest pada kelompok eksperimen memiliki total 3242 dengan rata-rata 101,31. Dari hasil rata-rata skor pretest dapat disimpulkan bahwa keterbukaan diri dalam komunikasi antar teman sebaya pada kelompok eksperimen sebelum diberikan treatment berupa bimbingan klasikal dengan teknik Johari Window tergolong dalam kategori tinggi. Sedangkan skor posttest pada kelompok eksperimen diperoleh total skor 3593 dengan rata-rata 112,28 yang dapat disimpulkan bahwa keterbukaan diri dalam komunikasi antar teman sebaya pada kelompok eksperimen setelah diberikan treatment berupa bimbingan klasikal dengan teknik Johari Window tergolong dalam kategori tinggi. Rata-rata hasil posttest keterbukaan diri dalam komunikasi antar teman sebaya menunjukan peningkatan dibandingkan dengan rata-rata hasil pretest pada skala keterbukaan diri. Dari data tersebut dapat dilihat bahwa ada peningkatan keterbukaan diri dalam komunikasi antar teman sebaya sebesar 10,97 setelah mendapatkan treatment.

$$
\text { Berdasarkan analisis data }
$$
menunjukkan bahwa ada peningkatan yang signifikan keterbukaan diri dalam komunikasi antar teman sebaya sebelum dan sesudah mendapatkan bimbingan klasikal dengan teknik Johari Window. Dari apa yang telah diuraikan di atas, dapat di simpulkan bahwa bimbingan klasikal dengan teknik Johari Window berpengaruh terhadap keterbukaan diri dalam komunikasi antar teman sebaya pada siswa kelas XII SMA Negeri 2 Rembang.

\section{SIMPULAN DAN SARAN}

Berdasarkan hasil pretest menunjukan adanya rata-rata keterbukaan diri dalam komunikasi antar teman sebaya pada siswa kelas XII SMA Negeri 2 Rembang kelompok kontrol 103,25 dan kelompok eksperimen 101,31, sedangkan hasil posttest menunjukan rata-rata keterbukaan diri dalam komunikasi antar teman sebaya pada siswa kelas XII SMA Negeri 2 Rembang kelompok kontrol sebesar 105,94 dan kelompok eksperimen 112,28. Rata-rata hasil posttest keterbukaan diri dalam komunikasi antar teman sebaya pada siswa kelas XII SMA Negeri 2 Rembang menunjukkan peningkatan dibandingkan dengan rata-rata hasil pretest dengan selisih skor 10,97\%.

Berdasarkan hasil penelitian diketahui bahwa Nilai thitung > ttabel $(2.103>2,042)$ dengan signifikansi $0,040 \quad(<0,05)$ yang berarti bahwa ada pengaruh bimbingan klasikal dengan teknik Johari Window untuk meningkatkan keterbukaan diri dalam komunikasi antar teman sebaya pada siswa kelas XII SMA Negeri 2 Rembang, sehingga hipotesis dalam penelitian ini diterima.

Melihat dari hasil penelitian, saran- saran yang diajukan peneliti adalah: Peserta didik dapat memanfaatkan bimbingan klasikal dengan teknik Johari Window sebagai bekal peserta didik dalam berkomunikasi secara interpersonal di lingkungan tempatnya berada. Bimbingan klasikal dengan teknik Johari Window diharapkan dapat menjadikan peserta didik semakin 
memahami pentingnya keterbukaan diri dalam komunikasi antar teman sebaya.

\section{DAFTAR PUSTAKA}

Chaplin, James. P. 2011. Kamus Lengkap Psikologi. Alih bahasa: Kartono. Jakarta: Bima Aksara.

Desmita. 2005. Psikologi Perkembangan Peserta Didik. Bandung: PT. Remaja Rosdakarya.

Nurudin. 2017. Ilmu Komunikasi: Ilmiah dan Populer. Jakarta: Rajawali Press.

Supratiknya, A. 1995. Komunikasi Antarpribadi Tinjauan Psikologis. Yogyakarta: Kanisius.

Siwabessy, Louise B. dan Sri Hastuti. 2008. Bahan Ajar Sertifikasi Guru Bimbingan dan Konseling dalam Jabatan melalui Jalur Pendidikan: Praktik Bimbingan Klasikal. Jakarta: Universitas Negeri Jakarta dan Dikti Depdiknas.

Setianingsih, Sari Eka. 2015.

Keterbukaan Diri Siswa. Jurnal Program Studi Pendidikan Guru Sekolah Dasar Universitas PGRI Semarang. Vol. 2 Nomor 2

Oktober ( ISSN 2406-8691)

Yusuf dan Nurihsan. 2008. Landasan Bimbingan dan Konseling. Bandung: Program Pascasarjana Universitas Pendidikan Indonesia dan Remaja Rosdakarya.

Zulkarnain, W. 2013. Dinamika Kelompok: Latihan Kepemimpinan Pendidikan. Jakarta: Bumi Aksara. 